\title{
A Case Report on a Patient with Chronic Kidney Disease on Therapy at a Tertiary Hospital in Lahore, Pakistan
}

\section{Munawar T and Sadeeqa $S^{*}$ \\ Institute of Pharmacy, Lahore College for Women University, Lahore, Pakistan}

*Corresponding author: Saleha Sadeeqa, Institute of Pharmacy, Lahore College for Women University, Lahore, Pakistan, Email: salehasadeeqa@gmail.com

\section{Case Report}

Volume 2 Issue 10

Received Date: September 10, 2018

Published Date: September 25, 2018

\section{Abstract}

Chronic kidney disorder is the progressive, irreversible damage to the kidney functions, as a result of which the renal replacement therapy is given in the form of dialysis (hemodialysis or peritoneal dialysis) and renal transplantation depending upon the patient condition, along with the medication therapy and lifestyle modifications. The focus of this study is to check the pharmaceutical care given to the patient of Chronic kidney disease on hemodialysis and the compliance of the patient to the therapy. The outcome of the therapy was to improve the patient's quality of life, slow down the progression of the disease and to avoid the complications associated with the therapy.

Keywords: CKD; Haemodialysis; Pharmaceutical Care; Quality of Life

\section{Background}

Kidney is the vital organ of our body that has to perform different biological functions like rennin secretion, excretion of the body waste material to maintain the homeostasis balance, regulation of the blood pressure, Vitamin-D activation to maintain the calcium and phosphate balance, acid-base regulation, red blood cell stimulation by erythropoietin production, urine formation and the electrolyte regulation like sodium, potassium, calcium, phosphate, magnesium, chloride. Sodium regulation is regulated by the hormone aldosterone. Vasopressin is a hormone involved in the kidneys, and is responsible for urine concentration and maintaining fluid balance. Chronic kidney disease (CKD) is the progressive, irreversible deterioration of renal functions, usually resulting from long standing disease, sometimes derives from acute renal failure that does not respond to treatment [1]. CKD occurs when the glomerulus filtration rate (GFR) falls below $30 \mathrm{ml} / \mathrm{min}$. It is caused by hypertension, diabetes, polycystic kidney disease, glomerulus disease and acute kidney injury [2].

CKD is classified into five different stages that are described below [3]:

\begin{tabular}{|c|c|c|c|}
\hline Stages & Qualitative description & $\begin{array}{c}\text { Renal function } \\
(\mathbf{m l} / \mathbf{m i n} / \mathbf{1 . 7 3} \mathbf{~ m 2})\end{array}$ & Actions \\
\hline 1 & $\begin{array}{c}\text { Kidney damage but normal } \\
\text { GFR }\end{array}$ & $\geq 90$ & $\begin{array}{c}\text { Diagnosis and treatment. Treatment of comorbid } \\
\text { conditions. Slowing progression CVD risk reduction }\end{array}$ \\
\hline 2 & $\begin{array}{c}\text { Kidney damage with mind } \\
\text { decrease in GFR }\end{array}$ & $60-89$ & Estimating progression \\
\hline
\end{tabular}




\section{Virology \& Immunology Journal}

\begin{tabular}{|c|c|c|c|}
\hline 3 & Moderate decrease in GFR & $30-59$ & Evaluating and treating complications \\
\hline 4 & Severe decrease in GFR & $15-29$ & Preparation for kidney Replacement and dialysis \\
\hline 5 & End stage renal disease & $<15$ & Replacement (if uremia present) and dialysis \\
\hline
\end{tabular}

Table 1: Stages of the CKD.

\section{Aims and Objectives}

Todetermine the pharmaceutical care of the end stage chronic kidney disease of the patient to improve the quality of life of that patient.

\section{Case Presentation}

A 45 years old hypertensive female patient diagnosed with end stage renal disease and was receiving the hemodialysis from last two years in a tertiary care hospital of Lahore Pakistan. She was married and a house wife. She was also overweight. Physician suggested to take the haemodialysis procedure two times a week with the prescribed medicine. She was admitted to HCV negative hemodialysis ward for the hemodialysis procedure.

\section{History of Present Illness}

The patient experiencing the chief complaints of abdominal distention, weakness, hyperuricemia, hyperphosphatemia, hypokalemia, shortness of breath and anemia.

\begin{tabular}{|c|c|}
\hline Chronic history & $\begin{array}{c}\text { She was suffering from chronic } \\
\text { kidney disease from last 2 years } \\
\text { and she was on haemodialysis } \\
\text { from past 2 years. }\end{array}$ \\
\hline Social history & $\begin{array}{c}\text { She belonged to the middle class } \\
\text { family. }\end{array}$ \\
\hline Family history & Her mother was hypertensive \\
\hline Occupational history & HOUSEWIFE \\
\hline ALLERGY & $\begin{array}{c}\text { No significant allergies ware } \\
\text { found }\end{array}$ \\
\hline
\end{tabular}

Table 2: History of past illness.

\begin{tabular}{|c|c|}
\hline Height & $162 \mathrm{~cm}$ \\
\hline Weight & $78 \mathrm{~kg}$ \\
\hline BMI & 29.7 \\
\hline Pulse rate & $88 \mathrm{beats} / \mathrm{mmHg}$ \\
\hline BP & $160 / 100 \mathrm{mmHg}$ \\
\hline Temperature & 98 \\
\hline
\end{tabular}

Table 3: General Examination.

\begin{tabular}{|c|c|c|c|}
\hline \multicolumn{4}{|c|}{ Hematological examination } \\
\hline & Result & Unit & Normal value \\
\hline Haemoglobin & 9.8 & $\mathrm{~g} / \mathrm{dl}$ & $\mathrm{F} 11.5-15.5$ \\
\hline Platelet count & 208 & $10^{\wedge} 9 / \mathrm{l}$ & $150-450$ \\
\hline WBC count & 5.8 & $10^{\wedge} 9 / \mathrm{l}$ & $11-\mathrm{Apr}$ \\
\hline ESR (fall in $1^{\text {st }}$ hour) & 90 & $\mathrm{Mm} / 1^{\text {st }}$ hour & $0-29$ \\
\hline
\end{tabular}

Table 4: Lab investigations.

\begin{tabular}{|c|c|}
\hline TESTS & Urine examination \\
\hline $\mathrm{pH}$ & 4.8 \\
\hline Specific gravity & 1.02 \\
\hline Albumin & $\begin{array}{c}\text { It was present in the urine, when the } \\
\text { physical and chemical analysis was } \\
\text { done }\end{array}$ \\
\hline $\begin{array}{c}\text { Blood in the } \\
\text { urine }\end{array}$ & $\begin{array}{c}\text { Blood was seen in the patient urine } \\
\text { sample containing red blood cells and } \\
\text { puss cells in adequate amount under } \\
\text { the microscopic examination of urine }\end{array}$ \\
\hline
\end{tabular}

Table 5: Lab investigations.

\begin{tabular}{|c|c|c|}
\hline Coagulation test & Values & Normal values \\
\hline PT & $12 \mathrm{Sec}$ & $12-17 \mathrm{Sec}$ \\
\hline APTT & $33 \mathrm{Sec}$ & $28-35 \mathrm{Sec}$ \\
\hline
\end{tabular}

Table 6: Coagulation test.

\begin{tabular}{|c|c|c|}
\hline Test & Value & Normal value \\
\hline Urea & $172.5 \mathrm{mg} / \mathrm{dl}$ & $7-20 \mathrm{mg} / \mathrm{dl}$ \\
\hline Creatinine & $9.0 \mathrm{mg} / \mathrm{dl}$ & $0.7-1.1 \mathrm{mg} / \mathrm{dl}$ \\
\hline Uric acid & $6.9 \mathrm{mg} / \mathrm{dl}$ & $2.4-6.0 \mathrm{mg} / \mathrm{dl}$ \\
\hline
\end{tabular}

Table 7: Renal Function test.

\section{Treatment}

\section{Pharmacological Treatment}

She was advised to visit the hospital 2 times a week for her hemodialysis procedure and take the prescribed medicines regularly as recommended. 


\section{Virology \& Immunology Journal}

\begin{tabular}{|c|c|c|c|c|}
\hline Brand name & Generic & Strength & Frequency & Indications \\
\hline Selanz-SR & Lansoprazole & $30 \mathrm{mg}$ & $\begin{array}{c}\text { One tablet once daily before } \\
\text { breakfast }\end{array}$ & For the stomach issues \\
\hline Adalat- R & Nefidipine & $20 \mathrm{mg}$ & One tablet after every 6 hours & To control B.P \\
\hline TropineInj & Erythropoitin & $4000 \mathrm{IU}$ & $\begin{array}{c}\text { Subcutaneously after every } \\
\text { dialysis }\end{array}$ & For anemia \\
\hline Zyloric & Allupurinol & $100 \mathrm{mg}$ & One tablet once daily & For hyperurecemia \\
\hline
\end{tabular}

Table 8: Prescribed Medicines.

\section{Non-Pharmacological Treatment}

The progression of the disease can be reduced by taking the medication along with dietary and lifestyle modifications. This can also improve the patient quality of life. Take the fluid in the limited amount to maintain the fluid status in the body. Take the high calories low protein diet. We can also recommend the kayexalate powder to such patients. Maintain the body weight and do exercise regularly as advised by the physician. Limit the intake of salt and potassium. Avoid soft drinks that contain phosphates. Avoid fatty food. Increase the fiber intake such as vegetables and fruits.

\section{Therapy Outcomes}

The treatment objectives are:

1. To improve the patient comfort and prolong the life.

2. To treat the systemic manifestations of CKD

3. Correct the body chemistry abnormalities.

\section{Follow Up}

1. Visit the hospital for the hameodialysis 2 times a week.

2. Maintain the electrolyte balance

3. Vitals must be checked before every procedure of the heamodialysis.

4. Take your medicines regularly, as prescribed by the physician, to avoid the complications.

5. Regularly monitor the glucose levels and blood pressure.

\section{Discussion}

The incidents of CKD are increasing day by day worldwide [4]. The estimated annual cases of end stage renal disease are greater than 100 per million populations in Pakistan [5]. The chronic kidney disorder causes by hypertension, diabetes, acute kidney injury, glomerulonephritis, polycystic kidney disease, drug induced [6]. The several complications may occur in the patient of CKD. The excretion of electrolytes through kidney is impaired causing the electrolyte imbalance. In addition to the serum hyperphosphatemia, the levels of calcium decreases occur due to which the patient may suffer from bone demineralization, fractures. Hyperkalemia causes the neuromuscular irritability which results in tingling sensation in fingers, restlessness, stomach cramping, diarrhea. The secretion of erythropoietin is also reduced due to kidney damage as a result of which the RBC'S production in the bone marrow decreases as a result of which anemia occurs. The levels of creatinine and urea clearance are also affected. As, the GFR decreases the levels of serum creatinine and decreases the urea clearance. The accumulation of urea causes the anorexia, nausea, vomiting and pancreatitis [7].

The metabolic acidosis is very common in the CKD patients as the bicarbonate ions (HCO3-) not formed and accumulation of hydrogen $(\mathrm{H}+$ )Ions occurs in the body due to impaired kidney. The conventional managerial approach to treat the CKD includes the dialysis and kidney transplantation.

The dialysis patients often complain the weakness, fatigue, difficulty in motion. This can be reduced by giving the physical therapy to the patient which will improve her quality of life.

Dialysis can be Hemodialysis or Peritoneal dialysis. In hemodialysis, the blood is removed from the body and filtered through artificial man -made membrane called dialyzer (artificial kidney) to remove the wastes and extra fluid from blood. The whole procedure requires 3-5 hours a day and done 3 times a week depending upon the patient condition. The most common disadvantage of hemodialysis is that the patient feel tired on the day of procedure [4].

In peritoneal dialysis, catheter is placed in the peritoneal cavity and inserted the dialysis fluid called dialysate to remove the waste and extra fluid from the body. The peritoneal dialysis is done on the ambulatory patients [8].

The greater expertise is required in the dialysis otherwise the patient may suffer from the serious 


\section{Virology \& Immunology Journal}

complications like air embolism, CVS problems, hepatitis, hyperglycemia, nausea, vomiting, anemia.

\section{Conclusion}

CKD is the growing problem worldwide and increasing day by day. The complications of the CKD can be minimized by the medications and lifestyle modifications. The focus of this study was to check the proper pharmaceutical care given to the CKD patient on hemodialysis to identify whether the care given to the patient is according to the patient needs or not. The therapy given to the patient must be safe, effective and the patient must be compliant to the therapy in order to avoid the further progression of the disease.

\section{References}

1. Abboud H, Henrich WL (2010) Stage IV Chronic Kidney Disease. New England Journal of Medicine 362(1): 56-65.

2. Unnati G (2013) Polyherabal Treatment for Chronic Kidney Disease-A Case Study. 2: 44-47.
3. Thomas R, Kanso A, Sedor JR (2008) Chronic Kidney Disease and Its Complications. Primary care 35(2): 329-344.

4. Zyoud SH, Daraghmeh DN, Mezyed DO, Khdeir RL, Sawafta MN, et al. (2016) Factors affecting quality of life in patients on haemodialysis: a cross-sectional study from Palestine. BMC Nephrology 17(1): 44.

5. Ullah K, Butt G, Masroor I, Kanwal K, Kifayat F (2015) Epidemiology of chronic kidney disease in a Pakistani population. Saudi Journal of Kidney Diseases and Transplantation 26(6): 1307-1310.

6. Kazancioğlu R (2013) Risk factors for chronic kidney disease: an update. Kidney International Supplements 3(4): 368-371.

7. Horigan A, Rocchiccioli J, Trimm D (2012) Dialysis and Fatigue: Implications for Nurses-A Case Study Analysis. Medsurg nursing 21(3): 158-175.

8. Alloatti S, Manes M, Paternoster G, Gaiter AM, Molino A, et al. (2000) Peritoneal dialysis compared with hemodialysis in the treatment of end-stage renal disease. J Nephrol 13(5): 331-342. 